\title{
A Study of Chinese Images in Pearl S. Buck's The Good Earth
}

\author{
Cao Ruoqi, Lu Jie* \\ College of Foreign Languages, Chengdu University of Information Technology, China
}

Received May 14, 2020; Revised June 29, 2020; Accepted July 20, 2020

\section{Cite This Paper in the following Citation Styles}

(a): [1] Cao Ruoqi, Lu Jie, "A Study of Chinese Images in Pearl S. Buck's The Good Earth," Linguistics and Literature Studies, Vol. 8, No. 5, pp. 264 - 268, 2020. DOI: 10.13189/lls.2020.080505.

(b): Cao Ruoqi, Lu Jie (2020). A Study of Chinese Images in Pearl S. Buck's The Good Earth. Linguistics and Literature Studies, 8(5), 264 - 268. DOI: 10.13189/lls.2020.080505.

Copyright $\mathrm{C} 2020$ by authors, all rights reserved. Authors agree that this article remains permanently open access under the terms of the Creative Commons Attribution License 4.0 International License

\begin{abstract}
Pear S. Buck is a famous American female writer and Nobel Prize winner in Literature in 1938. Buck has lived in China for 41 years. Chinese culture has a profound influence on her works. Most of her works reflect the conflict, understanding and integration of the two heterogeneous cultures between America and China. In recent years, the researches on Buck have boomed dramatically, while there is still a deficiency in the study of Buck's characterization of Chinese images from an American perspective. Based on the traditional images of Chinese in the Good Earth, this thesis reveals the characteristics of Chinese traditional family members shaped by Pearl S. Buck through analyzing the characters of a peasant family and their relations. At the same time, this thesis also explores the characteristics of the kinship relationship written by the native Chinese authors, and compares the two from a comparative perspective, so as to find out the differences between the images of traditional Chinese characters shaped by the American author, Pearl Buck, and other native Chinese writers as well as the causes of these differences.
\end{abstract}

Keywords Pearl S. Buck, The Good Earth, Chinese Images, Comparative Perspective

\section{Introduction}

Peal S. Buck is a controversial American writer who won Nobel Prize for Literature in 1938. Although she is an
American, she has lived in China for more than forty years. Most of her works are deeply involved with China. A cursory reading of her works can hardly identify the author's nationality, while if taking an in-depth look at her novels, it is not difficult to find that this great female American writer, who spent most of her life in China, has never escaped the influence of American culture. The Good Earth is Book One of The House of Earth Trilogy, which won the Nobel Prize for her. The Novel describes three generations of Chinese farmers and indicates their unique feeling towards earth. The Good Earth describes the hero Wang lung's whole life with his family, his experience from a poor young peasant to a rich landlord. O-Lan, Wang lung's wife, she is plain looking, dull and quiet, but she is a good housewife. She is diligent, loyal, thrifty, and competent. She owns many good qualities besides beauty, which makes her a good farmer's wife, but not a good landlord's wife. The story begins with this couple and their lives on the land in China, showing us the survival and development of an ordinary peasant family during the period of the Republic of China in Chinese Mainland when warlords were at war. At that time, Chinese society was in turmoil. The peasants were at the bottom of the society. Strictly speaking, based on the author's unique identity, the image study of Chinese characters in the Good Earth belongs to the category of cross-cultural image research. Studying the characters' images from different cultural angles and comparing them with the characters' images shaped by some native Chinese authors can deepen readers' understanding about the mechanism of image generation in fictions. 


\section{The Aphemic Mother O-Lan}

As a housewife, O-Lan is submissive and selfish, but devoted. This may be because of her childhood experience. O-Lan was born poor and was sold to the House of Hwang as a servant at very young age. She worked hard every day from morning to night. Yet despite working hard every day, she was beaten constantly and couldn't get a penny for herself. After her marriage to Wang Lung, as a poor farmer's wife, although she still lived a hard life every day, she lived much better than before.

O-Lan was diligent and silent. When she was pregnant for the second time, it was just in the busy farming season. Wang Lung blamed O-Lan for her pregnancy wasn't in the appropriate time, while O-Lan had no complaints.

She did everything silently. As soon as she gave birth to a child, she got out of bed immediately and helped her husband in the field for harvest. O-Lan is like a loyal and taciturn maid, silently serving her husband and never requesting anything for herself. In this novel, the climax of O-Lan's silence is the description of the episode about two pearls. The only thing she wanted to ask for is a pair of pearls. During their living in the southern city, O-Lan accidentally got some jewelry. Her husband discovered them and asked for this jewelry. O-Lan was almost timidly and pathetically begging Wang Lung to leave only two pearls to her. This was almost the only time that O-Lan requested her husband, but eventually, Wang Lung took away these peals for his concubine. Poor O-Lan cried silently.

As a mother, O-Lan was not amiable enough to her children; her maternal qualities were not distinct in comparison with other characters. In this novel, in the description of the love for children, Wang Lung's role is more obvious than that of O-Lan. In a famine year, O-Lan strangled her newborn daughter. The author didn't describe too much about O-Lan's inner world, instead, she depicted Wang Lung's sadness for this little girl. And when their younger son started to steal because of the poor life, Alan acquiesced in his behavior while Wang Lung would rather starve than eat what the child stole. So, Wang Lung fulfilled the duty as a father to educate his son but O-Lan did not.

In fact, mother is a very important role in the life of a traditional Chinese family. However, the image of O-Lan as a mother is obviously weakened, and the connection between O-Lan and the children is very loose. She always abandoned her children without any hesitation when facing with survival difficulties; she lived in her own fixed world because of her poor childhood, her husband's neglect and patriarchal society's oppression. The misfortunes that befallen her and her children causes her aphasia and make her lose the inherent maternal instinct.

From the perspective of the image of mother, the women in Lin Yutang's works seem to be more in line with the characteristics of traditional Chinese women. In his writings, motherhood is the most important role in a woman's life. For example, Yinping is a representative female character in Lin Yutang's Moments in Peking. She is a beautiful and cunning woman, she is also a servant girl who can do everything and endure all the humiliation in order to achieve her goal-marry to her young master. She seems to be flawless with strong will and determination. Unexpectedly, she finally commits suicide because her mother-in-law robs her of her child. Yinping's suicide shows the importance of children to mothers in traditional Chinese ideas, but in Pearl Buck's writings, O-Lan always gives up her children in the face of difficulties, which is quite different from the traditional female image shaped by Lin Yutang. Pearl Buck is just a bystander and outsider, although she has lived in China for many years. The traditional way of Chinese family organization is that men make decisions outside and women take charge of home. What Pearl Bucksaw in this family organization makes her see too many male rights and thus ignore the important role of women in a family. In fact, even in feudal China, mother is still the most important role of women in the family, but in Pearl Buck's writings, this role is replaced by her magnified patriarchal power, thus the image of O-Lan is distorted to be a silent woman lack of maternity. O-Lan is not a typically traditional Chinese mother, but she enables Buck to express her cultural shock at China's patriarchal system.

\section{The Tyrannical Father Wang Lung}

Wang Lung is a character with multiple identities in The Good Earth. As a son, Wang Lung is very filial. Before he got married, although he had to do heavy farm work by himself, the first thing he did when he got up was to take care of his father. It was not because of his father was ill or old-aged, just because of his filial piety infused by Confucianism. He was fulfilling a duty as a son. When the family had no food to eat, his father took it for granted to accept the last little food and didn't have to do anything to help the family get through the difficulties.

But, as a husband and father, Wang Lung has absolute control over his wife and son. With his hard work and wisdom, Wang lung succeeded in transforming himself from a poor peasant into a rich landowner. His success is inseparable from O-Lan's help. But after he became rich, he began to detest O-Lan in every way. He thought her ordinary appearance and dark skin made her unsuitable for a landlord. He had forgotten the days with O-Lan during his struggles, and only longed to share his wealth with a beautiful woman. As a co-creator of wealth, O-Lan had no right to reject her husband's decision. O-Lan accepted it calmly when Wang Long squandered the wealth he had earned with O-Lan on his second wife-Lotus. Wang Long cruelly snatched O-Lan's only precious jewelry to please lotus, O-Lan, like Wang Long's slave, worked day and 
night for the family and never enjoyed anything. All the wealth she created was controlled by her husband. As a father, Wang Lung laid down all the development paths for his sons, and he asked his eldest son to go to school so that his son would help him read when he signed contracts; he asked his second son to learn to do business, thus his business would be taken care of in the future, and he asked his third son to learn to farm, then his land would not be abandoned.

In the Good Earth, the image of father is relatively simple. Wang lung, as a father in a big family, keeps a tense relationship between him and his sons, which represents the feudal hierarchical family structure in China. When Wang lung died, his sons didn't have as much affection for him as a servant girl did. Such a father's image is obviously not in line with most Chinese fathers in reality. Although images of fathers shaped by Chinese authors are also silent and even autocratic like Wang lung, there is still deep love existing between fathers and sons.

In Zhu Ziqing's article "The Sight of Father's Back", the description of the father's bringing some tangerines for his son is especially touching. The father must cross the railway track before reaching the platform. The climbing was a strenuous job for the father, because he was overweight. The son watched the father hobbling towards the railway track, the father's hands held onto the upper part of the platform, his legs huddled up and his corpulent body tipped slightly towards the left, obviously making an enormous exertion. While the son was watching his father from behind, tears gushed from his eyes. From the description of this subtle scene, the image of father becomes vivid, real and moving.

As a foreign author, although Pearl Buck has a good understanding of Chinese culture, she is also deeply influenced by Western civilization, such as openness, equality and democracy. Patriarchal and hierarchy thinking is completely unacceptable for a modern western mind. When a western female writer who cherishes ideological democracy describes patriarchy, she often expresses father's right as a supreme right and ignores the existence of other rights, such as the rights of wife and son, which, although weak, have been struggling to grow and never completely obliterated. Therefore, in Pearl Buck's writing, the father, Wang Lung is shaped to be a symbol of magnified patriarchal power.

\section{Sons of Extreme Characters}

This part mainly focuses on the image of the sons in The Good Earth. The characters of the three sons are extremely different: Wang Da and Wang Er are absolute obedient, while Wang $\mathrm{Hu}$ is completely rebellious. Despite their difference, they are all indifferent to family affection. The images of the sons shaped by Pearl Buck are quite different from those by Chinese writers.
Wang lung had three sons, and as the absolute authority of the family, he dominated everything about them. When Wang Lung became rich, he was ashamed of his illiteracy and hoped that his son would make up for this defect. The eldest son was sent to receive school education according to Wang lung's arrangement. Wang Da didn't like studying at all, but to cater for Wang Lung's demands, he compromised. Wang Da inherited a strong lust for beautiful women from his father and is shaped to be a character without merit; he only relied on the land handed down by his father to live a life of prosperity. While he was the only one who respected his father's will to cherish the land. Although he did not create new values, he retained his father's land.

The second son Wang Er became a shrewd businessman under the arrangement of his father, and ran the business for his father, because Wang Lung already has an educated child and he hopes someone can help him to do business. Wang Er inherited his father's talent in doing business. Actually, because of this talent, Wang lung was able to successfully change from a farmer to a landlord. When Wang lung was poor, as long as he saved a little money, he would use it to buy more land. For the farmers of that time, this was undoubtedly wise. Wang Er grew as his father expected, he was good at making money, and he was always the richest man in this family, having the ability to help his brothers when they were lack of money.

Wang Da and Wang Er both took it for granted to obey their father's commands and thought obedience the first duty of a son. Besides, both of them bear some obvious hereditary traits from Wang Lung. So, in Pearl Suck's wrings, Wang Da and Wang Er are the representatives of traditional conformists in old Chinese family.

Wang Hu is Wang Lung's most favorite child. Wang Lung, the tyrant of the family, even made compromises with Wang Hu. Wang Lung's initial arrangement was to make Wang $\mathrm{Hu}$ a farmer, because he already had two children to do other things, and his land had to be taken care of. But Wang Hu didn't want to be a farmer at all. He wanted to go to school like his brother. From Wang Hu's point of view, as a child of a landlord, it was natural that he had the right to be educated, so the resistance this time was understandable and excusable.

The break between Wang Hu and his father is because of a servant girl- Li Hua. Wang $\mathrm{Hu}$ was very different from his eldest brother and father; he was not a man who was addicted to women. Wang Hu was only addicted to Li Hua in his life, a young servant in his house. But after he told his thoughts to his father, the old father married this young girl immediately, which made him disgusted. After that, Wang Hu had been away from his hometown for years, and Wang Lung had never seen his son again.

Wang $\mathrm{Hu}$ is a complete rebel. He hates all the influence his father imposes on him. He hates the land, thinking his father uses it to bind him. He also hates women, which may be because in his early years, he was hurt by his father 
because of Li Hua. The young girl fell in love with his elderly father, and this made Wang Hu disappointed in women all his life, and finally he was forced to marry a woman only because he wanted to have his own son. He is bent on becoming a warlord. It's hard to find anything in common between Wang $\mathrm{Hu}$ and his father. $\mathrm{He}$ is a thorough rebel who breaks away from his father both physically and spiritually.

In the Good Earth, the description of sons is in two extremes. Two are absolutely obedient and one is absolutely resistant. Actually, the images of sons should be pluralistic. And the children should have some resemblances to his father. In $\mathrm{Lu}$ Xun's article "Hometown", he describes Run Tu in the periods of adolescence and middle age. As a teenager, Run Tu was full of vigor and vitality, and full of hope for life. He didn't feel inferior to others because of his poverty. On the contrary, he played cheerfully with his friends from rich family and even taught him some new skills. While the portrayal of him in middle age is as follows: he had doubled his former size, his previously purplish, round face had turned grayish-yellow with deep wrinkles. His eyes resembled those of his father's. He swelled up in reddish color all over his body, which was somewhat like that for farmers living by the sea with exposure to sea breezes throughout the day. When he looked at his old friend, his stance finally turned respectful and said with distinct tone: Master. The hopeful Run Tu has gone and never come back. Honed by life, he finally became another image of his father.

The sons in the Good Earth are shaped to be flat characters, when Pearl Buck wants to highlight the character's shortcomings; it's almost hard for the readers to find any merit. For example, Wang Da is portrayed to be lazy, greedy and addicted to beauty, but in fact, Wang Da may have some good qualities, such as integrity and compassionate. Buck's description of this part is very brief. This may be related to Pearl Buck's acceptance of the Western binary opposition, in her eyes, the world is either black or white, with no room for shades of gray. But for the Chinese native writers, this boundary is vague; a person is usually both good and evil. It can be seen that Pearl Buck is more inclined to physical realism than psychological realism, which is often mixed with the author's strong subjective consciousness.

\section{The Mechanism of Creating Chinese Images in The Good Earth}

From the macro point of view, due to years of life in China, Pearl Buck's images of Chinese people are the most realistic ones shaped by foreign authors. But because of her unique American identity, under the influence of two different cultures between China and the United States, the images she created are distorted in some cases. For example, the failed marriage leads to the loss of kinship in family relations, and the unlimited amplification of patriarchy are exaggerated. All the differences may be attributed to the following three points-double take, Christian view of marriage, and her unique life experience.

The first cause is her double take. "I grew up in China, but I am not a member of China. I am an American, but I still not a member of it". These are Pearl Buck's own words about her identity. Pearl Buck grew up in China. When she was growing up, she knew China and regarded it as a real world. In her initial impression, the United States was a place full of fantasy and imagination existing in her mother's words. Although she had a deep sense of identity with China since childhood, as a white child, Pearl Buck felt deeply different from the Chinese children around her in many ways. For example, on one occasion, out of curiosity, she touched the braids of a Chinese child, and because of Pearl Buck's white identity, this act of playing among children made the Chinese child feel deeply humiliated. It was the first time that Pearl Buck really realized her American identity, and in the following time, the feeling became stronger and stronger. When she later returned to America to study, America was a strange but familiar place for her, since it had always existed in her mother's story. After living in China for many years, she was puzzled by the behavior of her peers around her. She found it difficult to integrate into the world that originally belonged to her. Her unique growth experience enables Pearl Buck to depict a real Chinese world, and it is really because of her unique identity that her Chinese world is slightly different from that of other Chinese of local writers. Even though she has lived in China for 41 years, Pearl Buck, as a middleman, inadvertently magnifies the difference in human nature between the Chinese and the Americans. In general, her depictions are close to reality, but an in-depth analysis will find that the characters, such as the silent mother, dominant father and obedient or rebellious sons, are all somewhat distorted.

The second cause is her Christian view of marriage. Religion is an important factor for exploring the difference in Chinese society between Peal Buck and some Chinese local authors. Pearl Buck was a daughter of a missionary. She believed in Christianity, which holds that marriage should be made by love combination instead of family line, and follows monogamy, promotes mutual respect, and pursuits equality between men and women in marriage. As a result, what many Chinese are used to following, such as polygamy and paternity, are incomprehensible to her. Her views were deeply reflected in her works. For example, at the beginning of the article, the author's unique perspective has been reflected in the description of Wang Lung's marriage. Arranged marriage was very common in China at that time. Poverty made Wang Lung dare not have too much hope for marriage. He married a plain-looking but robust woman who could help him reduce the burden of life. This is the best arrangement for Wang Lung, but in the 
author's writing, they become the familiar strangers. Judging from the follow-up of this marriage, O-Lan was very unfortunate. Even after her husband became rich, she did not enjoy the traditional right of the first wife and let others enjoy what she had created. Probably in the writings of other authors, O-Lan will own a happy life after her husband became rich, while in Pearl Buck's writing, she was full of misfortune, which almost owned to her Christian view of marriage that placed much emphasis on love and believed that love is the basis of marriage. In short, Buck's Christian view of marriage dooms O-Lan's marriage to fail from the very beginning. Without love, people in the family will lose a lot of emotions that they should have such as the mother's love for children, husband's love for wife, which is also one of the important reasons for the distortion of family characters.

The third one is her life experience, Although Pearl Buck, a daughter of a missionary, has lived in China for 40 years, why she has such a thorough understanding of the life of Chinese farmers is closely related to her husband. Pearl Buck's husband is an agronomist and often needs to go to the countryside to investigate agricultural production. Pearl Buck went to the countryside with her husband, which gave her more opportunities to have extensive contact with Chinese farmers and understand their living conditions. This experience made her intuitive experience of the hardship of Chinese farmers. These understandings not only provided a real background and affluent material for her future novel creation based on the Chinese countryside, but also laid a solid foundation for her famous novel-the Good Earth, which vividly shows the survival and development of Chinese peasant families.

\section{Conclusions}

The Good Earth is Pearl Buck's best work to win the Nobel Prize for Literature. In this book, she shows a complete Chinese peasant family's development process. It may be hard for the readers to find it is written by a foreign author. But there are still some differences between the Chinese characters shaped by her and some native Chinese authors. By comparing those characters, it found that the root of the differences is from the multicultural collision of the author's experience. When the causes of these differences gradually become clear, the heterogeneity between the two different cultures gradually appears. In general, as a foreign writer, Peal Buck has an excellent command of the images of Chinese farmers, which owns much to her many years of life experience in China and some knowledge from her husband who was engaged in agronomy research. But because of her foreign identity, the Chinese images she portrayed are not full enough and sometimes stereotyped compared with some other analogous characters shaped by Chinese native writers. The Chinese characters shaped by Buck in her The Good Earth are controversial in both China and America. However, it is precisely because of those controversies that they deserve further research from a cultural and historical point of view.

\section{Acknowledgments}

This essay is an achievement of the project "Ideological and Political Education in English and American Literature Courses" (BKJX2019073) supported by Chengdu University of Information Technology.

\section{REFERENCES}

[1] At Home in the World. Marriage and Family Living, Vol.4, No.1, Feb, 1942, pp.1-4.

[2] Buck, John Lossing, land Utilization in China. Nanjing: University of Nanjing, 1937

[3] China and the West. Annals of the American Academy of Political and Social Science, Vol.168, (Jul,1933), pp.118-131.

[4] George H. Danton. The Culture Contacts of the United States and China. Columbia University Press, 1931.

[5] Liao Kang, Pearl S. Buck: A Cultural Bridge Across the Pacific. (British Library Cataloguing in Publication Data available 1997).

[6] Lin, Yutang. Moment in Peking. Changsha; Hunan Nationalities Publishing House, 2016.

[7] Lu, Xun. Essays of Lu Xun. Shantou; Shantou Nationalities Publishing House, 2016.

[8] Meng, Hua. Imagology in Literature Comparatives. Beijing: Peking University Press, 2001.

[9] Of Men and Woman. New York; John Day Company, 1941.

[10] Pearl S. Buck; What American Means to me. New York; The John Day Company, 1934.

[11] Pearl S. Buck. China: As I See It (Compiled and Edited by Theodore F. Harris), New York: The John Day Company, 1970.

[12] Pearl S. Buck: The Good Earth. Britain: Mandarin Paperbacks, 1994.

[13] Pearl S. Buck. The Good Earth. New York; John Day Company, 1931.

[14] The Chinese Novel. New York; John Day Company, 1936.

[15] Zhu, Ziqing. Essays of Zhu Ziqing. Nanjing; Yilin Nationalities Publishing House, 2014. 